\title{
Improvement of adenoviral vector-mediated gene transfer to airway epithelia by folate-modified anionic liposomes
}

This article was published in the following Dove Press journal:

International Journal of Nanomedicine

24 May 2011

Number of times this article has been viewed

\author{
Zhirong Zhong ${ }^{1,2}$ \\ Yu Wan' \\ Jianfeng Han' \\ Sanjun Shi' \\ Zhirong Zhang' \\ Xun Sun'
}

'Key Laboratory of Drug Targeting and Drug Delivery Systems, Ministry of Education, West China School of Pharmacy, Sichuan University, Chengdu, Sichuan, People's Republic of China; ${ }^{2}$ Luzhou Medical College, Luzhou, Sichuan, People's Republic of China
Correspondence: Xun Sun

West China School of Pharmacy, Sichuan

University, Chengdu, Sichuan, People's

Republic of China, 6I 004 I

$\mathrm{Tel}+8602885502307$

Fax +86028 85501615

Email xunsun22@gmail.com

\begin{abstract}
Despite remarkable progress in the development of both viral and nonviral gene delivery vectors for airway disease treatment, poor gene transfer efficiency to the airway epithelium is a major obstacle in clinical application. To take advantage of the unique features of viral and nonviral vectors, we have developed complexes of adenovirus vector and anionic liposomes (AL-Ad5) by the calcium-induced phase change method. In the current study, based on the fact that there are overexpressed folate receptors on the surface of airway epithelia, we further modified the AL-Ad5 complexes with folate (F-AL-Ad5) to improve the transduction ability of Ad5 in airway epithelia. The transduction efficiencies of the obtained F-AL-Ad5 and AL-Ad5 complexes were assessed in primary-cultured airway epithelia in vitro. Our results indicated that compared with naked adenovirus vector, both AL-Ad5 and F-AL-Ad5 could significantly enhance the gene transduction efficiency of adenovirus vector in primary-cultured airway epithelial cells. Moreover, the enhancement mediated by F-AL-Ad5 was more dramatic than that by AL-Ad5. These results suggested that F-AL-Ad5 may be a useful strategy to deliver therapeutic genes to the airway epithelia and is promising in clinical application.
\end{abstract}

Keywords: gene delivery, adenovirus vector, folate receptor, primary-cultured airway epithelia

\section{Introduction}

Many studies have developed adenovirus-mediated gene transfer to cultured epithelial cells and various in vivo airway models, ${ }^{1-4}$ but low efficiency of gene transfer to the airway epithelium is a major obstacle to clinical application. ${ }^{5}$ It has been well documented that the uptake of adenovirus vector is dependent on the expression of coxsackievirus-adenovirus receptor (CAR) on the cell surface. ${ }^{6,7}$ However, Walters's study $^{8}$ demonstrated that CAR was not present on the apical surface of airway epithelium but located in the basolateral membrane. Thus, airway epithelial cell was a difficult target for gene therapy. To solve this key problem, high doses of virus and long periods of physical contact between the vector and targeted airway epithelial cells were commonly required for efficient gene transfer. But high doses of virus can initiate effective cellular and humoral immune responses. ${ }^{9,10}$ Moreover, the airway epithelium could respond to a range of stimuli by producing biologically active mediators such as cytokines, lipid mediators, peptide products, reactive oxygen species, and so on, which function to recruit circulating leukocytes to the airway, modulate airway tone, regulate secretions, and promote antimicrobial and antiviral activity. ${ }^{11}$ Furthermore, the extended vector contact with the airway epithelium was prevented by natural clearance mechanisms as well as mucous and soluble factors in the airway surface fluid. ${ }^{12}$ 
On the other hand, many studies have focused on the gene delivery system based on nonviral vectors. Among those nonviral vectors, cationic liposomes have been most widely studied and proved to be able to increase intracellular delivery potency and reduce inflammatory risk compared with viral vectors. However, a critical factor of transfection barriers is that upper-airway epithelial cells are covered by a negatively charged and viscous mucus layer that often traps and neutralizes the cationic liposome-DNA complexes, leading to inefficient transfection rate in vivo after topical administration. ${ }^{13,14}$ Furthermore, Duncan's results suggested that pulmonary surfactant inhibits cationic liposome-mediated gene delivery to respiratory epithelial cells. ${ }^{15}$ In addition, cytotoxicity of cationic liposomes should be of concern. These limitations restricted the application potential of cationic liposomal vectors in airway epithelia gene therapy.

Some studies have taken the anionic liposomal DNA delivery vectors as an alternative to cationic liposomes. ${ }^{16}$ Anionic lipids, in general, are less cytotoxic ${ }^{17}$ and some of them are the endogenetic components of eukaryotic cell membranes. ${ }^{18}$ It was demonstrated that a novel anionic lipoplex DNA delivery system encoding a gene of interest resulted in high transfection efficiency, good serum stability and low toxicity in vitro. ${ }^{19}$

Although much progress in nonviral vectors has been made, as mentioned above, the low transfection efficiency in vivo is still a major obstacle in their clinical applications. Therefore, it is urgent to develop some novel strategies to overcome these limitations and enhance gene expression in the airway epithelium. One of those novel strategies, combinations of viral and nonviral vectors, has been proposed for airway gene therapy. ${ }^{20,21}$ In a previous report, we developed a novel delivery system by incorporating adenovirus vector into the anionic liposomes referred as AL-Ad5. Transmission electron microscopy using a negative stain technique demonstrated that in AL-Ad5 the adenoviruses were surrounded by lipid membranes. We also demonstrated that this combination strategy significantly enhanced the adenovirus-mediated gene transfer to both MDCK and CHO cells which are deficient of coxsackie-adenovirus receptors. ${ }^{22}$

In our present study, to test whether such a combination strategy could improve the gene transducibility of adenovirus vector in CAR-deficient airway epithelia, we established and characterized a primary-culture model of differentiated murine tracheal epithelium. Moreover, according to the report that the polarized human airway epithelia expressed abundant folate receptors (FRs) on their apical surface, ${ }^{23}$ the folatemodified phosphoethanolamine (F-PE) was incorporated into the formulation to form the folate-modified AL-Ad5 complexes (F-AL-Ad5). The transduction efficiencies of both AL-Ad5 and F-AL-Ad5 were assayed in vitro.

\section{Materials and methods Materials}

The folate-modified egg phosphatidylethanolamine, folatepolyethyleneglycol-succinyl- egg $_{\text {phosphatidylethanolamine }}$ (F-PEG-SUC-EPE, F-PE), was synthesized as earlier reported $^{24}$ by reaction between F-PEG-NH (conjugate $_{2}$ prepared by folic acid and PEG-bis-amine) and SUCEPE (conjugate prepared by succinic anhydride and egg phosphatidylethanolamine). The fluorescein DHPE, $N$-fluorescein-5-thiocarbamoyl-1,2-dihexadecanoyl-sn-glycero3-phosphoethanolamine triethylammonium salt (excitation/ emission maxima $\sim 496 / 519 \mathrm{~nm}$ ) and 5-bromo-4-chloro-3indolyl- $\beta$-galactosidase (X-gal) were purchased from Invitrogen. The Ultroser-G serum substitute was obtained from Pall France/Division Pall BioPharmaceuticals (Pall 15950-017). The type VI acid-soluble human placental collagen (C7521) and mouse monoclonal anti-human pan cytokeratin (C2562) were from Sigma-Aldrich. FITC-labeled goat anti-mouse IgG (sc-2010) was purchased from Santa Cruz Biotechnology. The $\beta$-galactosidase enzyme assay system was from Applied Biosystems, and a bicinchoninic acid (BCA) assay kit was from Pierce, USA. The other agents such as $\mathrm{CaCl}_{2}$, ethylenediaminetetraacetic acid (EDTA), sodium pyruvate, Pronase, DNase and insulin were obtained from Sigma Chemical Co (St Louis, MO).

Specific pathogen-free C57BL/6N male mice, 5-7 weeks old, were purchased from the Laboratory Animal Center of Sichuan University (Chengdu, China). The study was approved by the Animal Ethics committee of Sichuan University West China Medical School, and all procedures with animals were conducted according to the guidelines of the local Animal Use and Care Committees of Chengdu and executed according to the National Animal Welfare Law of China.

The adenovirus vectors used for this study are based on the Ad5 backbone, E1/E3-deleted. Ad5-LacZ expressing $\beta$-galactosidase was purchased from the Vector Gene Technology Company (VGTC, Beijing, China). The adenovirus titre was detected using plaque-forming assay on HEK 293 cells. ${ }^{25}$

\section{Preparation of F-AL-Ad5 and optimization of folate-PE mole ratio in formulation of F-AL-Ad5}

The folate-modified complexes of adenoviral anionic liposomes (F-AL-Ad5) were prepared by the calcium-induced phase 
changes method according to a previous report. ${ }^{22}$ Briefly, the lipid mixture of PC/CHEMS/Chol/folate-PE (5:4:1:0.01 mol/ mol) was dissolved in chloroform and dried into a thin film on the wall of a 12-mm glass tube under a stream of nitrogen gas. The film was further dried under reduced pressure for 4 hours to ensure no trace of chloroform. Then, the dried, thin film was hydrated with Tes-buffered saline $(100 \mathrm{mM} \mathrm{NaCl}, 2 \mathrm{mM}$ histidine, $2 \mathrm{mM}$ Tes, pH 7.4). Blank folate-modified anionic liposomes (F-AL) were formed by sonicating for 100 seconds intermittently $(100 \mathrm{~W})$ in an ice-bath sonicator. $\mathrm{Ca}^{2+}$ was introduced by direct addition of $100 \mathrm{mM} \mathrm{CaCl}_{2}$ to the preformed F-AL (final concentration $10 \mathrm{mM}$ ) and incubated at $25^{\circ} \mathrm{C}$ for 1 hour. The resulting precipitate was pelleted by centrifuging at $2500 \times g$ for 10 minutes. The pellet was resuspended at a lipid concentration of $10 \mu \mathrm{mol} / \mathrm{mL}$ in a concentrated viral solution by vortexing for 10 minutes at room temperature. EDTA $(100 \mathrm{mM})$ was added directly to this solution with a final concentration of $15 \mathrm{mM}$, and $10-20 \mu \mathrm{L}$ of $100 \mathrm{mM} \mathrm{NaOH}$ was added to adjust the $\mathrm{pH}$ to 7.4 . The solution was vortexed for 10 minutes followed by incubation for 30 minutes to form the folate-modified complexes of adenoviral anionic liposomes $\left(8.5 \times 10^{8}\right.$ viral particles/mg lipids).

Three types of fluorescently labeled formulations were prepared, in which the varying molar ratio of folate-PE was $1 \%, 5 \%$, and $10 \%$, respectively. Additionally, to fluorescently label the formulations, $1 \%$ fluorescein DHPE was included in the lipid component of each formulation. The polarized primary-cultured tracheal epithelial cells were used to test the cell uptake of the preformed fluorescently labeled formulations by flow cytometric analysis at excitation of $488 \mathrm{~nm}$ (BD FACS Canto II Flow Cytometer, USA).

\section{Isolation and culture of tracheal epithelial cells}

The primary culture of tracheal epithelia was carried out by an air-liquid interface method as the previous reports described. ${ }^{26,27}$ Firstly, the following four kinds of solution are prepared including the collection media, dissociation media, culture media, and differentiation media in the same way the reports described. ${ }^{26,27}$ Then, mice tracheae were obtained from $\mathrm{C} 57 \mathrm{BL} / 6 \mathrm{~N}$ mice and digested with dissociation media at $37^{\circ} \mathrm{C}$ for 60 minutes. The digestion was stopped with fetal calf serum. The cells were pelleted $(200 \times g$ for 10 minutes $)$ and suspended in culture medium. This suspension was incubated at $37^{\circ} \mathrm{C}$ for 2 hours in a 100 -mm culture dish (Corning, USA) to remove the nonepithelial cells. Nonadherent cells were collected, washed, and seeded at $4 \times 10^{5}$ cells in $200 \mu \mathrm{L}$ of culture medium inside the transwell inserts
(Costar Transwell clear, $0.4 \mu \mathrm{m}$ pore) which were precoated with type VI acid-soluble human placental collagen, with $600 \mu \mathrm{L}$ culture medium outside. The cells were incubated at $37^{\circ} \mathrm{C}$ in $6 \% \mathrm{CO}_{2}$ in a humidified incubator for 3 days. The medium inside of the insert was removed along with any nonadherent cells and debris, and the medium outside (bathing the basolateral surface) was replaced with $600 \mu \mathrm{L}$ of differentiation media on day 4, then twice weekly. Any apical fluid should be sucked off every day, and the apical side should not be fed. Once the cells have reached confluence and formed tight junctions, the transduction studies were carried out.

\section{Evaluation of the primary-cultured tracheal epithelium cells}

Epithelia were tested for transepithelial resistance $\left(R_{\mathrm{te}}\right)$ by a Millicell-ERS (Electrical Resistance System, Millipore) and for morphology by scanning electron microscopy (SEM), taking the tracheal specimens from 5-week-old mice as control. SEM was performed according to the previous report. ${ }^{26}$ Briefly, before viewed under a JSM-5900LV (JEOL, Japan) scanning electron microscope, the samples were washed with phosphate buffered saline (PBS), and then fixed firstly in PBS with $2.5 \%$ glutaraldehyde and secondly in $1 \%$ osmium tetroxide in PBS. Subsequently, the specimens were dehydrated through an alcohol series, treated with hexamethyldisilazane, and allowed to air-dry overnight.

To investigate the presence of cytokeratin, which was proved to be a typical character of airway epithelia, a fluorescence immunohistochemistry test was performed on primary-cultured cells using mouse monoclonal antihuman pan cytokeratin (Sigma-Aldrich, C2562) as a primary antibody and FITC-labeled goat anti-mouse IgG as a secondary antibody (Santa Cruz Biotechnology Inc, CA).

\section{Infection of polarized primary cultures of murine tracheal epithelium cells by naked Ad5, AL-Ad5, and F-AL-Ad5}

Fourteen days after seeding, the polarized primary cultures of murine tracheal epithelium cells were rinsed twice with PBS and then infected by adding $50 \mu \mathrm{L}$ of the formulation of naked Ad5, AL-Ad5, and F-AL-Ad5 to the apical surface and the basolateral surface of the cultures, respectively. When infected from basolateral sides, the epithelia were turned upside down and $50 \mu \mathrm{L}$ of formulation solution carefully applied to the bottom of the costar filter. A multiplicity of infection (MOI) of 40 was used in all transductions. After 4 hours, the suspension was removed, the cells were rinsed twice with PBS, and $200 \mu \mathrm{L}$ of the culture medium was added 
to the inside insert and $600 \mu \mathrm{L}$ to the outside insert. One day after infection, the transduction efficiency was assayed by $\mathrm{X}$-gal staining and quantifying the LacZ gene expression, in which the $\beta$-galactosidase activities were determined using the $\beta$-galactosidase enzyme assay system (Applied Biosystems), and the total protein content of the lysates was measured by a BCA assay (Pierce, USA) using a standard of bovine serum albumin (BSA). Infectivity was quantified as pictogram of $\beta$-galactosidase (based on a standard curve for $\beta$-galactosidase activity) per microgram of total cell protein ( $\mathrm{pg} / \mu \mathrm{g}$ protein). The data were represented as mean \pm standard deviation (SD) of three wells and was representative of three independent experiments.

The function of EDTA in the transduction of naked Ad5 was investigated. The naked Ad5 formulation was prepared in exactly the same way as the AL-Ad5 was prepared. As described above, during preparation of AL-Ad5 formulation, EDTA was introduced by calcium-induced phase changes method then diluted with DMEM medium at a final concentration of $1 \mathrm{mM}$. Therefore, the naked Ad5 prepared by the calcium-induced phase changes method also contained $1 \mathrm{mM}$ EDTA when the transduction was performed. Meanwhile, the naked Ad5 solution containing $10 \mathrm{mM}$ EDTA was also prepared. The transduction process was carried out in the same way as the operation mentioned above.

\section{Statistical analysis}

At least two independent sets of experiments were carried out, with similar results obtained. The results from one set were chosen to show in the present paper. Data obtained were represented as mean $\pm \mathrm{SD})$ and statistically analyzed using one-way ANOVA with Bonferroni post-tests $(P<0.05$; $P<0.01)$.

\section{Results}

Particle size and zeta potential of folatemodified complexes of adenovirus vector and anionic liposomes (F-AL-Ad5)

Figure 1 shows the schematic structure representation of F-AL-Ad5. The average particle size of F-AL-Ad5 (1\% folate-PE) detected by Malvern Zetasizer Nano ZS90 (Malvern instruments Ltd, UK) was $225 \pm 18 \mathrm{~nm}$ with a PDI (polydispersity index) of 0.253 , which was similar to the size of AL-Ad5 $(211 \pm 10 \mathrm{~nm})(P>0.05)$. There was also little difference in zeta potential between F-AL-Ad5 and AL-Ad5 $(-42.5 \pm 1.8 \mathrm{mV}$ for F-AL-Ad5 versus $-42.2 \pm 2.2 \mathrm{mV}$ for AL-Ad5, $P>0.05)$.

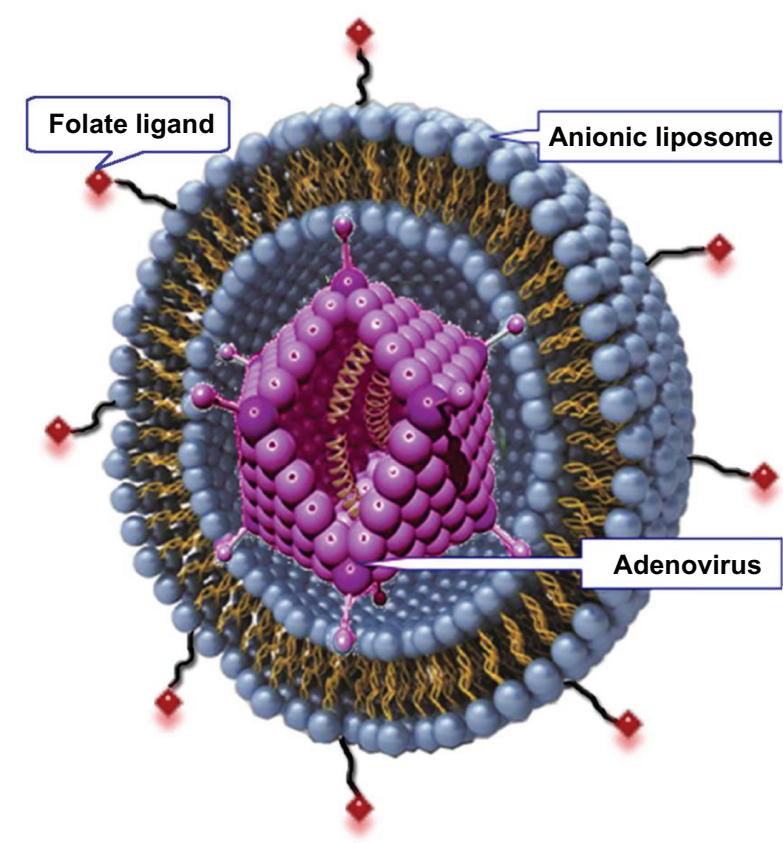

Figure I Schematic representation of the structure of folate-modified adenoviral anionic liposome complexes (F-AL-Ad5).

\section{Characterization of primary-cultured airway epithelia}

To test whether the primary culture of airway epithelia was performed successfully, investigations such as the morphology detection under light fields, SEM detection, $R_{\text {te }}$ detection, and fluorescence immunohistochemistry assay for cytokeratin were carried out. Some of the results are summarized in Figure 2. From the light fields' images (Figure 2, A1-A2) under invert microscope, it could be seen that there were some island-like cells on the surface layer (Figure 2, A1) from day 8. SEM was performed on primary-culture murine tracheal epithelial cells at a different time point, taking the tracheal specimens from 5-week-old animals of the same strain as control. A flattened epithelium was observed on day 4, with no features of differentiation. However, SEM analyses on days 8 and 21 revealed $13 \% \pm 2 \%(n=3$ observations $)$ and $21 \% \pm 3 \%$ ( $\mathrm{n}=3$ observations) ciliated cells, ${ }^{26}$ respectively. By day 25 , the percentage of ciliated cells was $26 \% \pm 5 \%$ ( $n=2$ observations) (Figure 2: B2). The result of immunohistochemical analyses on day 8 (Figure 2: $\mathrm{C} 1, \mathrm{C} 2$ ) demonstrated the presence of cytokeratins, which was a typical characteristic of murine airway epithelial cells. The $R_{\text {te }}$ detection result indicated that the transepithelial resistance of the primary-cultured cells was $2000-3000 \Omega \mathrm{cm}^{2}$ from day 4, then decreased and stabilized at about $1000 \Omega \mathrm{cm}^{2}$ by day 14 , which indicated the cultured cells were well polarized. 

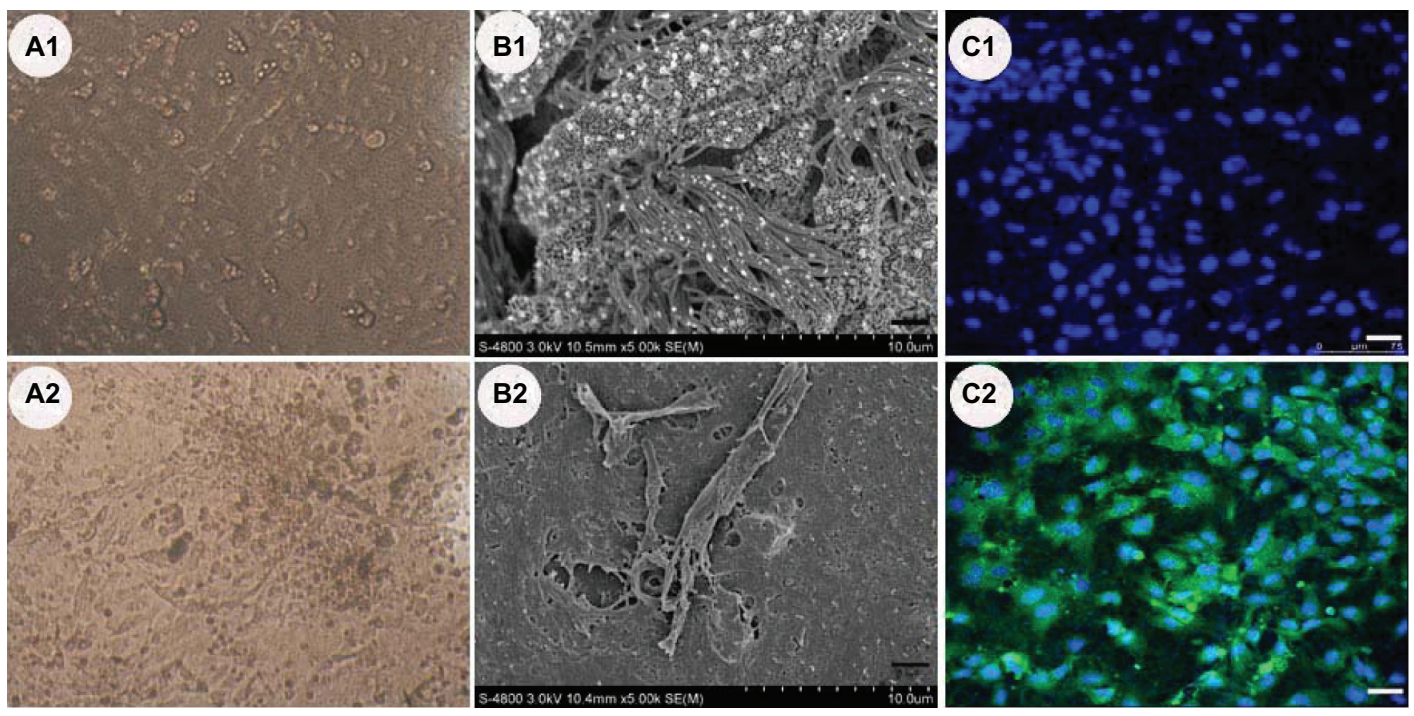

Figure 2 Characterization on the primary-cultured airway epithelia. AI, A2) $(\times 200)$ Cells under the light fields with some island-like cells on the surface layer $\mathbf{A}$ ) . BI, B2) Scanning electron micrographs of a 5-week-old mouse trachea BI) and primary cultures of murine tracheal epithelium on day 25 B2). C2) Immunohistochemical detection of cytokeratins characterized in primary-culture murine tracheal epithelial cells with a negative control of $\mathbf{C I}$ ). The bar in $\mathbf{B I}$ ) and $\mathbf{B 2}$ ) is $2 \mu \mathrm{m}$ and that of $\mathbf{C I}$ ) and $\mathbf{C 2}$ ) is $30 \mu \mathrm{m}$.

\section{Optimization of folate-PE by quantification of cell uptake using flow cytometry}

The optimal ratio of folate-PE used to prepare F-AL-Ad5 was determined by quantification of cell uptake using flow cytometry. As shown in Figure 3, when the molar ratio of folate-PE in the total lipid was $1 \%$, the uptake ratio of liposomes into tracheal epithelial cells was the highest. Therefore, $1 \%$ of folate-PE (molar ratio) was used to prepare the formulation of F-AL-Ad5 in the following experiment.

\section{Gene expression in the primary-cultured airway epithelia}

To evaluate the transduction efficiency of obtained F-AL-Ad5 and AL-Ad5 complexes in primary-cultured cells, the formulation solutions were added dropwise to the apical and basolateral surfaces, respectively. When infected from basolateral sides, the transwell inserts were turned upside down and $50 \mu \mathrm{L}$ of formulation solution carefully applied to the bottom of the costar filter. Additionally, in our preliminary experiments, we investigated the formulation's transduction efficiencies with MOI of 20,40, and 80 (pfu), respectively. The results indicated that at different MOI of adenovirus vectors, the tested groups exhibited similar alteration tendency of transduction efficacies. At MOI 40, the readout was sensitive enough to detect the LacZ gene expression. Therefore, in the present study, we carried out all the transduction experiments at MOI 40.
The result (Figure 4) showed that a higher LacZ expression was observed in the group of cells infected from the apical surface by AL-Ad5 and F-AL-Ad5 compared with cells infected with naked adenovirus vector $(P<0.01)$. Among all the tested formulations, we observed that F-ALAd5 significantly increased the transfection efficiency along the polarized airway epithelia $(P<0.01)$. Moreover, the transfection of F-AL-Ad5 could be competitively inhibited by $0.1 \mathrm{mM}$ or $1 \mathrm{mM}$ free folic acid (Figure 5), indicating that the cellular delivery of F-AL-Ad5 is mediated by folate receptors.

We also found that reduced transfection efficiency occurred when F-AL-Ad5 was administered basolaterally. This indicated the absence of FR at the basolateral side of murine airway epithelia. Additionally, LacZ expression of naked-adenoviral infected cells was significantly higher when the treatment was applied basolaterally compared with that applied apically. This suggested that naked adenovirus vector had the ability to infect polarized airway epithelia via the basolateral side, which may be due to the presence of CAR on the basolateral membrane. ${ }^{8}$

The result of transduction efficiency mediated by naked Ad5 with or without EDTA is demonstrated in Figure 6. Both the profile of qualitative $X$-gal staining (Figure 6A) and quantitative detection of LacZ gene expression (Figure 6B) indicated that EDTA could enhance the transduction efficiency of naked Ad5 in the polarized epithelium cells. Figure 6B shows that in the group of naked Ad5 with $1 \mathrm{mM}$ EDTA, the transduction efficiency 

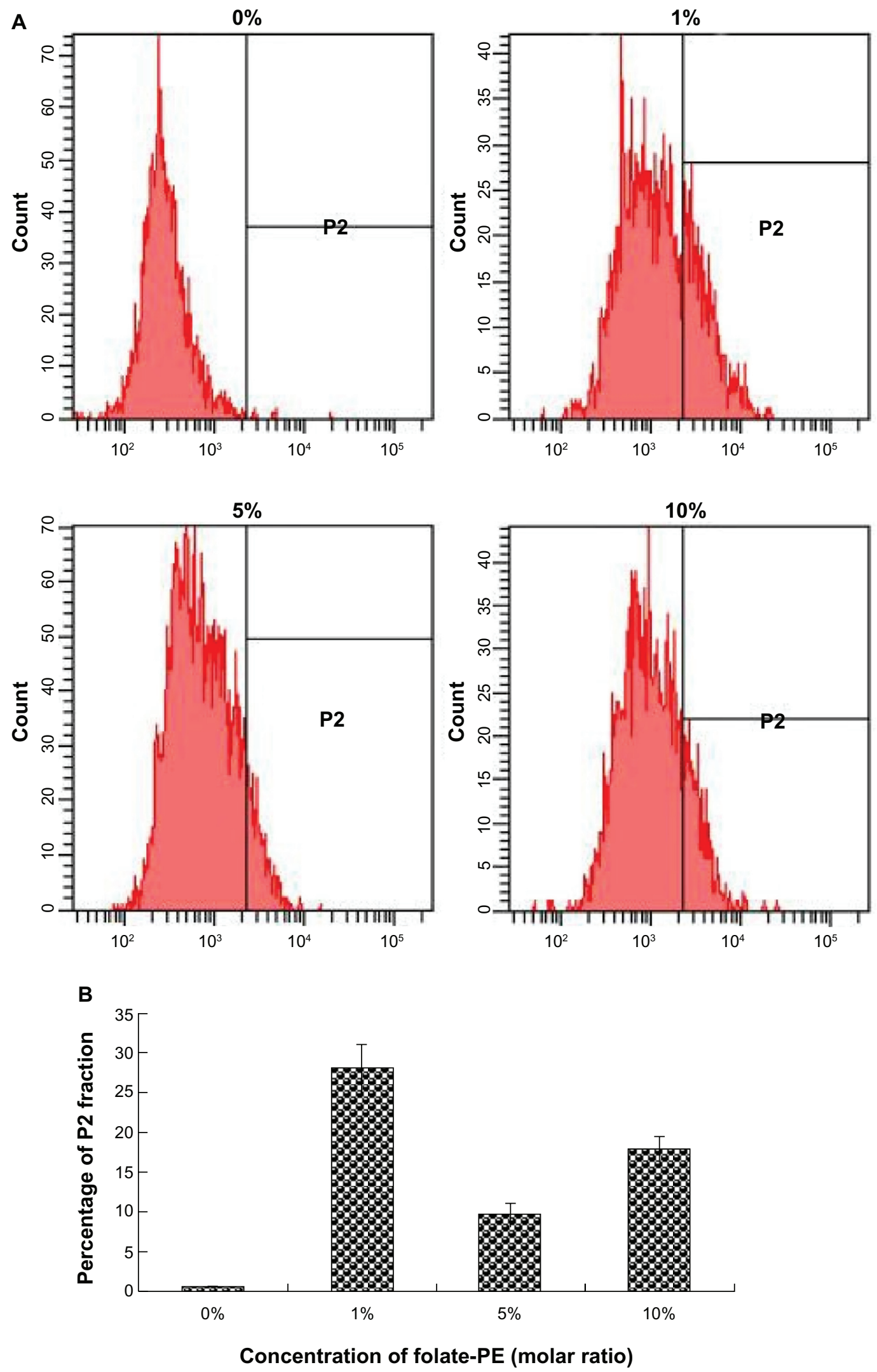

Figure 3 Flow cytometry data after incubation of fluorescently labeled F-AL-Ad5 with the polarized primary-cultured tracheal epithelial cells for 4 hours at $37^{\circ} \mathrm{C}$. The profile of cell population count and fluorescence intensity A), and profile of the percentage parent in P2 area with concentration of folate-PE B) indicated the $1 \%$ formulation led to the highest uptake among all the test formulations.

Abbreviations: F-AL-Ad5, folate-modified complexes of adenovirus vector and anionic liposomes; folate-PE, folate-modified phosphoethanolamine; P2, positive cells. 

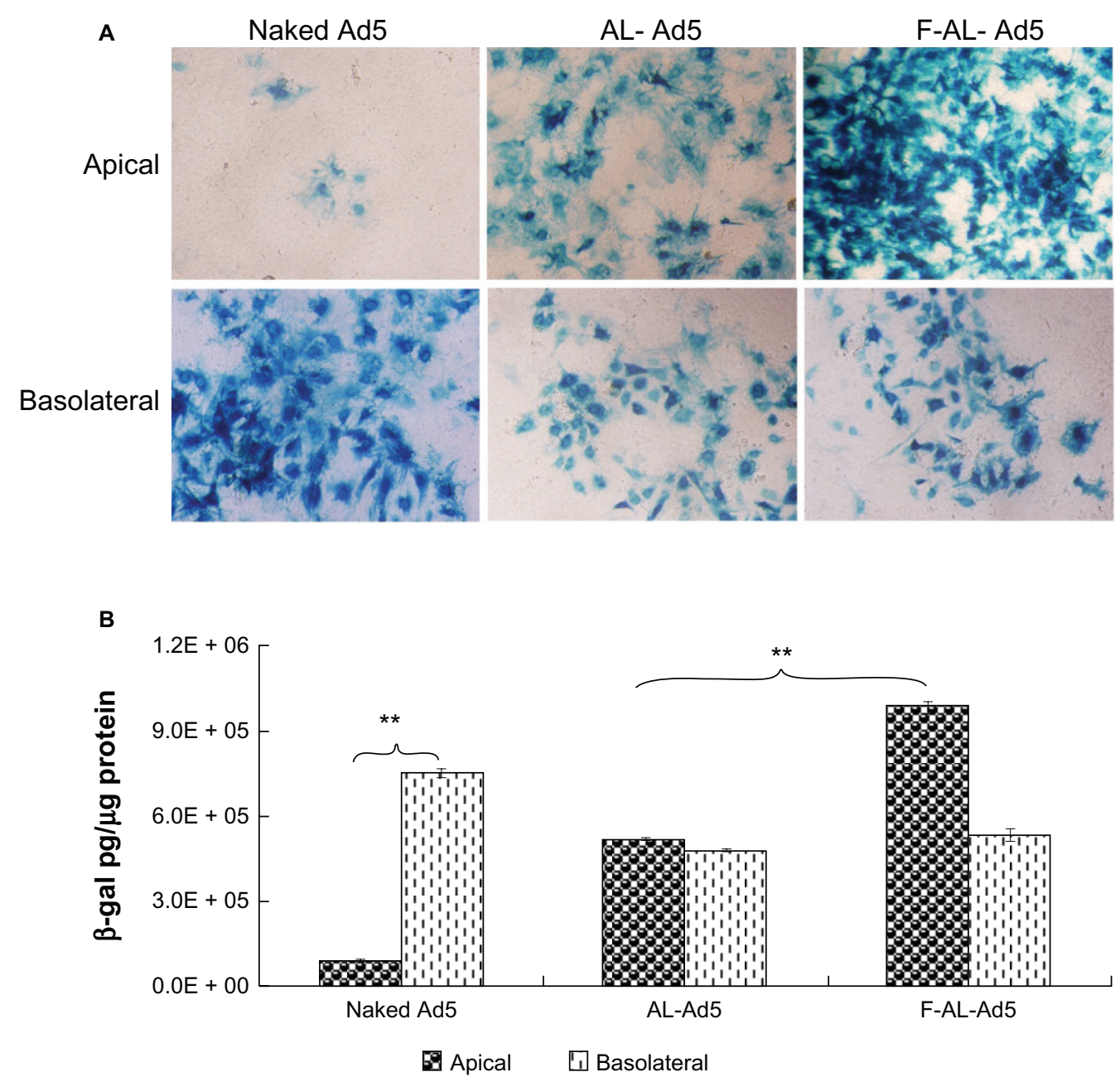

Figure 4 Transduction levels of polarized primary-cultured tracheal epithelial cells. Primary cultures were transduced with naked Ad5 (MOI 40), AL-Ad5, and F-AL-Ad5 (total lipids $0.2 \mathrm{mg} / \mathrm{mL}$ ), containing Ad5-LacZ at an MOI of 40 applied to the apical and basolateral surface, respectively, followed by X-gal staining A) ( $\times 200$ ) and quantitative detection of $\beta$-galactosidase gene expression $\mathbf{B}$ ).

Notes: Results are presented as mean \pm standard deviation $(n=3), * P<0.05$, ** $P<0.0$ I, ANOVA.

Abbreviations: Ad5, adenovirus vector; $\mathrm{AL}$, anionic liposome; F, folate; MOI, multiplicity of infection.

was 2.2-fold higher than that in the group without EDTA. When the concentration of EDTA increased to $10 \mathrm{mM}$, the transduction efficiency increased $\sim 8.15$-fold. This result suggested the contribution of EDTA for higher gene expression of F-AL-Ad5 and AL-Ad5.

\section{Discussion}

Improving the efficiency of gene transfer remains an important goal in developing new treatments for cystic fibrosis and other diseases. Adenovirus vectors and nonviral vectors each have specific advantages, but they also have limitations. Adenovirus vectors can efficiently escape from the endosome and enter the nucleus, but the virus shows limited binding to airway epithelia. Nonviral cationic vectors can be efficiently internalized by airway epithelia, but they do not catalyze subsequent steps in gene transfer. In our previous study, the combination strategy of anionic liposomes and adenovirus vector was found to increase the efficiency of adenovirusmediated gene transfer to coxsackie-adenovirus receptor deficient cells. ${ }^{22}$ In this novel delivery system, by incorporating adenovirus vector into liposomes, we were able to take advantage of adenovirus-dependent processes that facilitate gene expression such as escape from the endosome and entry into the nucleus. ${ }^{28}$ These processes are significant barriers to nonviral vector-mediated gene transfer.

In the present study, we hypothesized that combination strategy could also improve the efficiency of gene transduction mediated by adenovirus vector in CAR-deficient airway epithelium. The transduction results suggested the LacZ gene expression mediated by naked Ad5 from the apical side was as poor as predicted due to lack of CAR on the apical surface of airway epithelia. But the complexes of AL-Ad5 increased 


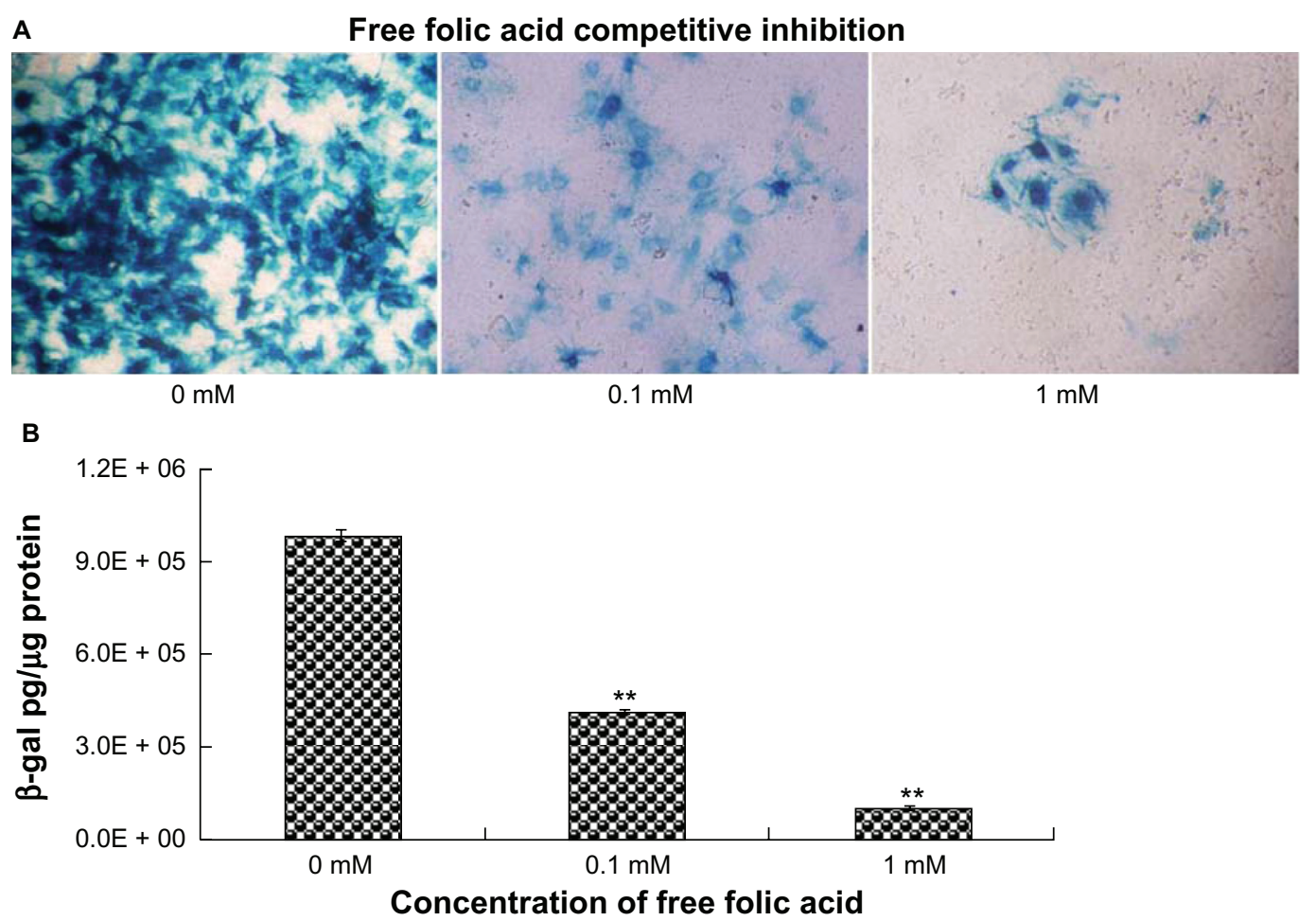

Figure 5 Inhibition effect on $L a c Z$ gene expression enforced by free folic acid. The primary-cultured tracheal epithelial cells were pre-incubated with $50 \mu \mathrm{L}$ of free folic acid $(0,0.1, I \mathrm{mM})$ before adding the F-AL-Ad5 transfective agent to the apical surface followed by X-gal staining $\mathbf{A})(\times 200)$ and quantitative detection of $\beta$-galactosidase gene expression B).

Notes: Results are presented as mean \pm standard deviation $(n=3), * P<0.05$, **P $<0.0$ I, ANOVA.

Abbreviations: $A d 5$, adenovirus vector; $A L$, anionic liposome; $F$, folate.

the LacZ gene expression when infected from the apical side. This result was consistent with a previous paper reporting that anionic liposomes increased the efficiency of adenovirusmediated gene transfer to CAR deficient cells. ${ }^{22}$

Additionally, an ideal gene carrier system should efficiently accumulate in specific target tissues with minimal toxicity to nontarget tissues. ${ }^{29}$ In order to specifically increase transfection efficiency of delivering system to targeted cell populations, various targeting ligands including antibodies, growth factors, peptides, transferrin, and folate have been conjugated to polymers and lipids. ${ }^{30,31}$ Folate receptors are vastly over-expressed in a wide variety of human tumors, but rarely are found on normal cell surfaces. ${ }^{32}$ To further facilitate the uptake of AL-Ad5 by airway epithelia, folate was incorporated into this delivery system based on the report that the polarized human airway epithelia expressed abundant FR on their apical surface. ${ }^{23}$ The obtained results in this study indicated that folate modification to AL-Ad5 complexes could further enhance the gene transduction in airway epithelium in vitro and the enhancement could be inhibited by free folate in the medium, suggesting FR was playing an important role in the gene transduction of airway epithelia. Meanwhile, when these folate-modified AL-Ad5 complexes were applied to transduce the human ovarian cancer cells SKOV3, which are rich in folate receptors ${ }^{33}$ and deficient of coxsackie-adenovirus receptors, ${ }^{34}$ a dramatic enhancement of gene expression was observed compared with that of unmodified AL-Ad5 complexes (data not shown). This result also suggested ligand modification was a useful approach to further improve the uptake of AL-Ad5 complexes by the targeted cell population.

In previous reports, airway epithelia cell lines such as CRL-9483 or 16HBE14o- cells were used to evaluate the efficiency of gene transfer, ${ }^{35,36}$ but the air-liquid interface primary-cultured airway epithelial cells are more appropriate models in vitro to assess transduction efficiency of carriers in airway epithelia, which accurately represents the behavior of polarized, differentiated airway epithelial cells. Therefore, in the current study, we set up a primaryculture model of differentiated mouse tracheal epithelium on semipermeable support membranes. The characteristics of the primary-culture model were investigated by SEM, immunohistochemistry, and electrophysiology, which confirmed the successful establishment of this model.

To further explore the possible reason that anionic liposomes could enhance the transduction level of Ad5 in 


\section{A}

Role of EDTA playing on the transduction of naked Ad5

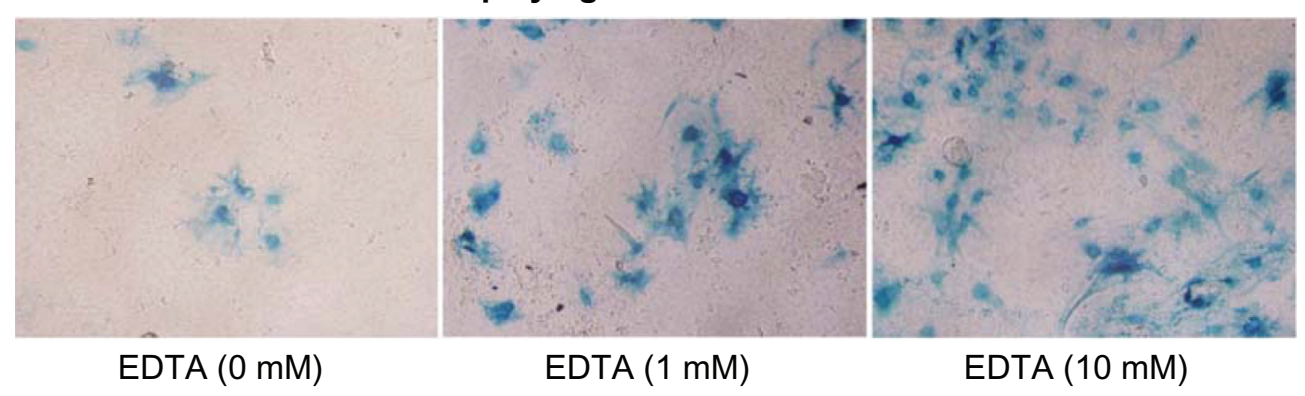

B

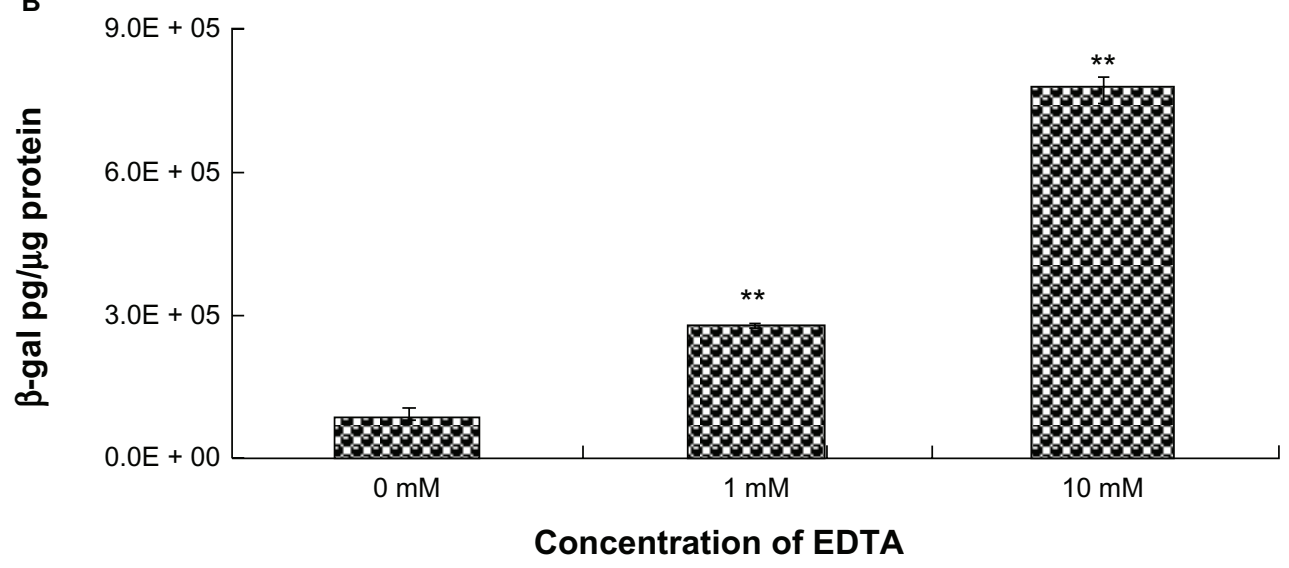

Figure 6 Effect of EDTA on the transduction of naked Ad5. EDTA was mixed with naked Ad5 solution before the transduction at a final concentration of I and I0 mM, respectively. These mixtures containing Ad5-LacZ at an $\mathrm{MOI}$ of 40 were applied to the primary-cultured tracheal epithelia from the apical surface followed by $\mathrm{X}$-gal staining A) $(\times 200)$ and quantitative detection of $\beta$-galactosidase gene expression B).

Notes: Results are presented as mean \pm standard deviation $(n=3)$, *P<0.05, **P $<0.0$ I, ANOVA.

Abbreviations: Ad5, adenovirus vector; EDTA, ethylenediaminetetraacetic acid; MOI, multiplicity of infection.

airway epithelium, we investigated the function of EDTA on transduction. It was known that the CAR was located at the basolateral side of airway epithelia, and the tight junctions (TJs) play a central role in sealing the intercellular space between the apical and basolateral compartments of epithelial and endothelial cells. Therefore, when adenoviral vectors were applied to the mucosal surface of airway epithelia, the transduction efficiency was poor. Modulation of the barrier function of the TJ has been investigated as a strategy to enhance transmucosal drug absorption. ${ }^{37-39}$ Some agents such as a phospholipid detergent, surfactant, ethyleneglycol-bis (2-aminoethyl ether)-N,N,N',N'-tetraacetic acid (EGTA) are attractive as potential therapies to enhance absorption of gene transfer vectors due to the rapid onset of action (within minutes) and their relatively rapid recovery (within hours) after treatment. ${ }^{40}$ It has been reported that the integrity of the intercellular junctions requires a finite concentration of extracellular $\mathrm{Ca}^{2+}$. Removal of $\mathrm{Ca}^{2+}$ by chelators such as EGTA leads to significant increases in paracellular permeability and gene transfer efficiency. ${ }^{41,42}$ It was reported that gene transfer via the apical surface of human airway epithelia in vitro was improved by formulating vectors with EGTA in a hypotonic buffer. When $\mathrm{Ca}^{2+}$ chelators were applied to rabbit tracheal epithelia or human nasal epithelia in vivo, the transepithelial voltage decreased, and amiloride sensitivity was lost, suggesting that epithelial junctions opened. ${ }^{43,44}$ In our study, the complexes of anionic liposomes and adenovirus vector (AL-Ad5) were prepared under the help of EDTA by the calcium-induced phase changes method. A final concentration of $1 \mathrm{mM}$ of EDTA remained in the obtained formulation of AL-Ad5 complexes. EDTA is also one kind of $\mathrm{Ca}^{2+}$ chelator, whose structure and function are similar to EGTA. When used in murine airway epithelia, AL-Ad5 exhibited an increased gene expression compared with naked adenovirus vector. To investigate whether the enhanced gene expression was due to the residual EDTA or the lipid formulation, different concentrations of EDTA was added to naked Ad5 before the transduction. As shown in Figure 6, when naked Ad5 was mixed with $1 \mathrm{mM}$ EDTA, whose concentration was the same as that in the formulation of AL-Ad5 or F-AL-Ad5, 
a 2.2-fold enhancement of gene expression was observed in primary-cultured differentiated cells. But the increased transduction efficacy was still lower than that obtained by the formulation of AL-Ad5 $(2.72 \pm 0.13) \times 10^{5}$ for naked Ad5 versus $(5.15 \pm 0.81) \times 10^{5}$ for AL-Ad5, $\left.P<0.05\right)$. These results suggested that the higher transduction efficiency of AL-Ad5 was not only due to the residual EDTA, but was also contributed to by the formation of Ad5-liposome complexes. EDTA could open the tight junction of airway epithelia according to the other reports. ${ }^{43,44}$ Meanwhile, in our previous experiments, no cytotoxity was observed on A549 cells for the AL-Ad5 formulation. ${ }^{22}$

\section{Conclusion}

In the present study, we prepared the complexes of anionic liposomes and adenovirus vector (AL-Ad5) by the calciuminduced phase changes method, and also incorporated folate-PE into lipid components to obtain folate-modified complexes (F-AL-Ad5). The results from the in vitro study indicated that in primary-cultured airway epithelial cells, AL-Ad5 and especially F-AL-Ad5 showed significant enhancement in gene transduction efficiency. This novel gene delivery system may be a useful strategy to deliver therapeutic genes to airway epithelia in vivo and other cells with overexpressed folate receptor.

\section{Acknowledgments}

We are thankful for the financial support of the National Natural and Science Foundation of China (No. 30973657) and the National Science and Technology Major Project of China (No. 2009ZX09310-002). We also thank Prof Weiyao $\mathrm{Lu}$ in Fudan University for synthesizing folate-PE.

\section{Disclosure}

The authors report no conflicts of interest in this work.

\section{References}

1. Goldman MJ, Yang Y, Wilson JM. Gene therapy in a xenograft model of cystic fibrosis lung corrects chloride transport more effectively than the sodium defect. Nat Genet. 1995;9(2):126-131.

2. Rosenfeld MA, Yoshimura K, Trapnell BC, et al. In vivo transfer of the human cystic fibrosis transmembrane conductance regulator gene to the airway epithelium. Cell. 1992;68(1):143-155.

3. Zabner J, Petersen DM, Puga AP, et al. Safety and efficacy of repetitive adenovirus-mediated transfer of CFTR cDNA to airway epithelia of primates and cotton rats. Nat Genet.1994;6(1):75-83.

4. Zuckerman JB, Robinson CB, McCoy KS, et al. A Phase I study of adenovirus-mediated transfer of the human cystic fibrosis transmembrane conductance regulator gene to a lung segment of individuals with cystic fibrosis. Hum Gene Ther. 1999;10(18):2973-2985.

5. West J, Rodman DM. Gene therapy for pulmonary diseases. Chest. 2001;119(2):613-617.
6. Tomko RP, Xu R, Philipson L. HCAR and MCAR: the human and mouse cellular receptors for subgroup $\mathrm{C}$ adenoviruses and group B coxsackieviruses. Proc Natl Acad Sci U S A. 1997;94(7): 3352-3356.

7. Vigl B, Zgraggen C, Rehman N, Banziger-Tobler NE, Detmar M, Halin C. Coxsackie- and adenovirus receptor (CAR) is expressed in lymphatic vessels in human skin and affects lymphatic endothelial cell function in vitro. Exp Cell Res. 2009;315(2):336-347.

8. Walters RW, Grunst T, Bergelson JM, Finberg RW, Welsh MJ, Zabner J. Basolateral localization of fiber receptors limits adenovirus infection from the apical surface of airway epithelia. J Biol Chem. 1999;274(15): 10219-10226.

9. Griesenbach U, Alton EW. Gene transfer to the lung: lessons learned from more than 2 decades of CF gene therapy. Adv Drug Deliv Rev. 2009;61(2):128-139.

10. Iwamoto HS, Trapnell BC, McConnell CJ, Daugherty C, Whitsett JA. Pulmonary inflammation associated with repeated, prenatal exposure to an E1, E3-deleted adenoviral vector in sheep. Gene Ther. 1999;6(1):98-106.

11. Polito AJ, Proud D. Epithelia cells as regulators of airway inflammation. J Allergy Clin Immunol. 1998;102(5):714-718.

12. Knowles MR, Boucher RC. Mucus clearance as a primary innate defense mechanism for mammalian airways. J Clin Invest. 2002;109(5): 571-577.

13. Gao X, Kim KS, Liu D. Nonviral gene delivery: what we know and what is next. AAPS J. 2007;9(1):E92-E104.

14. Rosenecker J, Naundorf S, Gersting SW, et al. Interaction of bronchoalveolar lavage fluid with polyplexes and lipoplexes: analysing the role of proteins and glycoproteins. J Gene Med. 2003;5(1):49-60.

15. Duncan JE, Whitsett JA, Horowitz AD. Pulmonary surfactant inhibits cationic liposome-mediated gene delivery to respiratory epithelial cells in vitro. Hum Gene Ther. 1997;8(4):431-438.

16. Srinivasan C, Burgess DJ. Optimization and characterization of anionic lipoplexes for gene delivery. J Control Release. 2009;136(1):62-70.

17. Patil SD, Rhodes DG, Burgess DJ. Anionic liposomal delivery system for DNA transfection. AAPS J. 2004;6(4):e29.

18. Liang H, Harries D, Wong GC. Polymorphism of DNA-anionic liposome complexes reveals hierarchy of ion-mediated interactions. Proc Natl Acad Sci U S A. 2005;102(32):11173-11178.

19. Patil SD, Rhodes DG, Burgess DJ. Biophysical characterization of anionic lipoplexes. Biochim Biophys Acta. 2005;1711(1):1-11.

20. Croyle MA, Cheng X, Sandhu A, Wilson JM. Development of novel formulations that enhance adenoviral-mediated gene expression in the lung in vitro and in vivo. Mol Ther. 2001;4(1):22-28.

21. Price A, Limberis M, Gruneich JA, Wilson JM, Diamond SL. Targeting viral-mediated transduction to the lung airway epithelium with the anti-inflammatory cationic lipid dexamethasone-spermine. Mol Ther. 2005;12(3):502-509.

22. Zhong Z, Shi S, Han J, Zhang Z, Sun X. Anionic liposomes increase the efficiency of adenovirus-mediated gene transfer to coxsackie-adenovirus receptor deficient cells. Mol Pharm. 2010;7(1):105-115.

23. Sinn PL, Hickey MA, Staber PD, et al. Lentivirus vectors pseudotyped with filoviral envelope glycoproteins transduce airway epithelia from the apical surface independently of folate receptor alpha. J Virol. 2003;77(10):5902-5910.

24. Lu WY, Liu M, Pan J, Li H, Ma J. Preparation of folate-liposome and its delivery into cultured HeLa Cells. J Shanghai Med Univ. 2000; 27:4-8.

25. Mittereder N, March KL, Trapnell BC. Evaluation of the concentration and bioactivity of adenovirus vectors for gene therapy. J Virol. 1996;70(11):7498-7509.

26. Davidson DJ, Kilanowski FM, Randell SH, Sheppard DN, Dorin JR. A primary culture model of differentiated murine tracheal epithelium. Am J Physiol Lung Cell Mol Physiol. 2000;279:766-778.

27. Davidson DJ, Gray MA, Kilanowski FM, et al. Murine epithelial cells: isolation and culture. J Cyst Fibros. 2004;2:59-62. 
28. Fasbender A, Zabner J, Chillon M, et al. Complexes of adenovirus with polycationic polymers and cationic lipids increase the efficiency of gene transfer in vitro and in vivo. J Biol Chem. 1997;272(10):6479-6489.

29. Luten J, van Steenbergen MJ, Lok MC, et al. Degradable PEG-folate coated poly(DMAEA-co-BA)phosphazene-based polyplexes exhibit receptorspecific gene expression. Eur J Pharm Sci. 2008;33(3):241-251.

30. Hashimoto M, Morimoto M, Saimoto H, Shigemasa Y, Sato T. Lactosylated chitosan for DNA delivery into hepatocytes: the effect of lactosylation on the physicochemical properties and intracellular trafficking of pDNA/chitosan complexes. Bioconjug Chem. 2006;17(2):309-316.

31. Kim YK, Choi JY, Yoo MK, et al. Receptor-mediated gene delivery by folate-PEG-baculovirus in vitro. J Biotechnol. 2007;131(3):353-361.

32. Sudimack J, Lee RJ. Targeted drug delivery via the folate receptor. Adv Drug Deliv Rev. 2000;41(2):147-162.

33. Zheng Y, Cai Z, Song X, et al. Preparation and characterization of folate conjugated $\mathrm{N}$-trimethyl chitosan nanoparticles as protein carrier targeting folate receptor: in vitro studies. J Drug Target. 2009; 17(4):294-303.

34. Kim JS, Lee SH, Cho YS, Choi JJ, Kim YH, Lee JH. Enhancement of the adenoviral sensitivity of human ovarian cancer cells by transient expression of coxsackievirus and adenovirus receptor (CAR). Gynecol Oncol. 2002;85(2):260-265.

35. Issa MM, Koping-Hoggard M, Tommeraas K, et al. Targeted gene delivery with trisaccharide-substituted chitosan oligomers in vitro and after lung administration in vivo. J Control Release. 2006;115(1):103-112.

36. Tu HY, Chen X, Li J. Signal transduction in respiratory syncytial virus infection-induced thymic stromal lymphopoietin expression in human epithelial cells. Nan Fang Yi Ke Da Xue Xue Bao. 2007;27(10): $1581-1583$.
37. Morimoto K, Nakamura T, Morisaka K. Effect of medium-chain fatty acid salts on penetration of a hydrophilic compound and a macromolecular compound across rabbit corneas. Arch Int Pharmacodyn Ther. 1989;302:18-26.

38. Soderholm JD, Oman H, Blomquist L, Veen J, Lindmark T, Olaison G. Reversible increase in tight junction permeability to macromolecules in rat ileal mucosa in vitro by sodium caprate, a constituent of milk fat. Dig Dis Sci.1998;43(7):1547-1552.

39. Coyne CB, Ribeiro CM, Boucher RC, Johnson LG. Acute mechanism of medium chain fatty acid-induced enhancement of airway epithelial permeability. J Pharmacol Exp Ther. 2003;305(2):440-450.

40. Lindmark T, Schipper N, Lazorova L, de Boer AG, Artursson P. Absorption enhancement in intestinal epithelial Caco-2 monolayers by sodium caprate: assessment of molecular weight dependence and demonstration of transport routes. J Drug Target. 1998;5(3):215-223.

41. Duan D, Yue Y, Yan Z, McCray PB Jr, Engelhardt JF. Polarity influences the efficiency of recombinant adenoassociated virus infection in differentiated airway epithelia. Hum Gene Ther. 1998;9(18): 2761-2776.

42. Coyne CB, Kelly MM, Boucher RC, Johnson LG. Enhanced epithelial gene transfer by modulation of tight junctions with sodium caprate. Am J Respir Cell Mol Biol. 2000;23(5):602-609.

43. Wang G, Zabner J, Deering C, et al. Increasing epithelial junction permeability enhances gene transfer to airway epithelia In vivo. Am J Respir Cell Mol Biol. 2000;22(2):129-138.

44. Myles C, Sorscher E, Matalon S. Enhancement of adenovirusmediated gene transfer in lungs and epithelial cells by EGTA. Chest. 2002;121(Suppl 3):35S
International Journal of Nanomedicine

\section{Publish your work in this journal}

The International Journal of Nanomedicine is an international, peerreviewed journal focusing on the application of nanotechnology in diagnostics, therapeutics, and drug delivery systems throughout the biomedical field. This journal is indexed on PubMed Central, MedLine, CAS, SciSearch $®$, Current Contents ${ } /$ Clinical Medicine,

\section{Dovepress}

Journal Citation Reports/Science Edition, EMBase, Scopus and the Elsevier Bibliographic databases. The manuscript management system is completely online and includes a very quick and fair peer-review system, which is all easy to use. Visit http://www.dovepress.com/ testimonials.php to read real quotes from published authors 